\title{
Peningkatan Minat Belajar Siswa Melalui Pembelajaran E-Learning Via Whatsapp di Kelas X MIPA Madrasah Aliyah Hasanah Pekanbaru
}

\author{
Dicky Rian ${ }^{1}$, Zulfah $^{2}$ \\ ${ }^{1,2}$ Program Studi Pendidikan Matematika, Fakultas Ilmu Pendidikan, Universitas Pahlawan Tuanku Tambusai, \\ Jl.Tuanku Tmbusai No 23, Bangkinang, Indonesia. \\ dickyrian312@gmail.com
}

\begin{abstract}
This research is based on the low interest in student learning towards teaching and learning activities through online. Because there is a limited knowledge of students who are not sensitive to technology and information, some students complain because of the difficulty in accessing this online learning. Even so, there are several learning applications that are free, but because of the low interest in students learning about learning applications and because of a lack of understanding of how to use them, here the researchers conducted student observations of online learning via WhatsApp. The purpose of this study was to determine how much influence the increase in online learning via WhatsApp on student interest in learning. This research is a collaborative classroom action research between the researcher, the teacher as the subject giving action and the students as the recipient of the action. This research was conducted at MA Hasannah in class X MIPA, with 13 students. The data collection method used by researchers is in the form of filling out a questionnaire using google form, while the research instrument is the questions that are presented on the questionnaire filling sheet on the google form. In this study it can be concluded that there is low student interest in online learning so that it affects student learning outcomes, so the solution is to use the WhatsApp application in online learning.
\end{abstract}

Key Words: Interest To Learn; E-learning; WhatsApp

\begin{abstract}
ABSTRAK
penelitian ini di latar belakangi oleh rendahnya minat belajar siswa terhadap kegiatan belajar mengajar melalui Daring. Karena adanya sebuah keterbatasan pengetahuan siswa yang tidak peka terhadap teknologi dan informasi maka sebagian siswa mengeluh karena kesusahan untuk mengakses pembelajaran melalui Daring ini. Walaupun demikian ada beberapa aplikasi belajar yang gratis, tetapi karena rendahnya minat belajar siswa terhadap aplikasi-aplikasi belajar dan karena kurangnya pemahaman cara menggunakannya, maka disini peneliti melakukan observasi siswa terhadap pembelajaran Daring Via WhatsApp. Tujuan dilakukannya penelitian ini untuk mengetahui seberapa besar pengaruh peningkatan pembelajaran Daring Via WhatsApp terhadap minat belajar siswa. Penelitian ini adalah penelitian tindakan kelas yang sifatnya kolaboratif antara peneliti, guru sebagai subjek pemberi tindakan dan siswa sebagai subjek penerima tindakan. Penelitian ini dilakukan di MA Hasannah pada kelas X MIPA yang siswanya berjumlah 13 orang. Metode pengumpulan data yang dipakai peneliti berupa pengisisan kuesioner yang menggunakan google form, sedangkan Instrumen penelitian ini adalah pertanyaan-pertanyaan yang tersaji pada lembar pengisian kuesioner pada google form. Pada penelitian ini dapat disimpulkan bahwasannya terdapat minat belajar siswa yang rendah pada pembelajaran Daring sehingga mempengaruhi hasil belajar siswa, sehinnga di dapat solusinya adalah penggunaan aplikasi whatsApp pada pembelajaran Daring. Dapat ditunjukan bahwasannya siswa lebih menyukai aplikasi yang mudah digunakan serta tidak memerlukan aplikasi lain untuk mengelola tugas nya seperti dengan judul peneliti yaitu menggunakan aplikasi WhatsApp dalam pembelajaran Daring ini.
\end{abstract}

Kata Kunci: Minat Belajar; E-learning; WhatsApp

Copyright (C) 2021 Dicky Rian, Zulfah

$\triangle$ Corresponding author: Dicky Rian

Email Address: dickyrian312@gmail.com (Jl. Tuanku Tambusai No 23 Bangkinang, Indonesia)

Received 28 Januari 2020, Accepted 30 Desember 2020, Published 27 Februari 2021

\section{PENDAHULUAN}

Pandemi Covid-19 atau merebaknya virus corona bermula di wilayah Wuhan, China. Wabah Covid-19 ini, sekarang telah masuk ke Indonesia dan menginfeksi lebih dari 1 juta orang. Corona 
mengubah semua aspek kehidupan bangsa Indonesia, terutama bidang pendidikan/pengajaran. Respon yang cepat diketahui dengan adanya Surat Edaran Mendikbud RI, Nomor 36962 /MPK.A/HK/2020 mengenai Pembelajaran yang dilakukan melalui sistem online atau virtual tanpa tatap muka serta bekerja dari rumah dalam rangka mencegah perluasan tersebarnya Corona Virus Disease (COVID19). Penelitian mengenai dampak Covid-19 pada pendidikan di Indonesia ini pun sudah diteliti oleh (Syah, 2020), (Purwanto et al., 2020), (Abidah, Hidaayatullaah, Simamora, Fehabutar, \& Mutakinati, 2020), dan (Alchamdani, Eka, Anugrah, Sari, \& Freddrika Putri, 2020).

Penyebaran virus corona ini pada awalnya sangat berdampak bagi dunia ekonomi yang mulailesu, dan akhirnya kini berdampak juga dirasakan oleh dunia pendidikan. Kebijakan yang sudah diambil oleh banyak negara dan termasuk Indonesia juga dengan meliburkan seluruh aktivitas pendidikan, dan membuat pemerintah dan lembaga terkait harus menghadirkan alternatif untuk proses pendidikan bagi peserta didik maupun mahasiswa yang sekarang tidak bisa melaksanakan proses pembelajaran atau proses pendidikan pada suatu lembaga pendidikan (Dewi, 2020).

Berdasarkan situasi sekarang yang sedang melanda negeri ini yaitu adanya bencana non alam yang diakibatkan oleh penyebaran Corona Virus Disease 19 (covid-19), maka diberlakukanlah pembelajaran Daring yang dilakukan oleh sistem lembaga pendidikan di seluruh Indonesia. Kegiatan belajar mengajar yang diberlakukan menggunakan Daring ini membuat sebagian Siswa ataupun guru menjadi merasa semakin susah, di karenakan berbagai aspek yang mempengaruhinya salah satunya menurunya minat belajar siswa. Pada saat terjadi pembelajaran luring atau bertemu dengan peserta didik, maka akan terjadi kontak langsung diantara pendidik dan peserta didik. Ketika terjadi pertemuan langsung tersebut, dimungkinkan adanya penyebaran corona. Menurut perihal inilah, Pembelajaran daring masih merupakan pembelajaran yang cocok untuk kondisi saat ini. Suatu hal yang penting diperhatikan yaitu Pasal 31 (3) UU RI Nomor 20 Tahun 2003. Isi dari Pasal 31 (3) menyebutkan PJJ dilakukan pada bermacam rupa, modus, dan jangkauan yang disupport oleh sarana dan pelayanan belajar. Suatu sarana pembelajaran dimana dimungkinkan tersirat pada Pasal 31 (3) ini yaitu jaringan internet (Hidayat, 2020) .

Penelitian ini dilakukan guna mengetahui seberapa besar peningkatan minat belajar siswa melalui pembelajaran Daring via WhatsApp. Penelitian ini dilakukan berdasarkan wawancara terhadap guru mata pelajaran disampaikan bahwasannya minat belajar siswa rendah terhadap pembelajaran daring dikarenakan beberapa faktor salah satunya ialah keterbatasan pemahaman terhadap mengelola media pembelajaran daring yang ada. Maka dari itu peneliti mencoba untuk menggunakan media pembelajaran daring WhatsApp untuk melihat seberapa meningkat minat belajar siswa terhadap pembelajaran daring via WhatsApp.

Berkaitan dengan proses belajar, Purwanto (2010: 85) mengatakan belajar merupakan suatu perubahan dalam tingkah laku dimana perubahan tersebut dapat mengarah kepada tingkah laku lebih baik, tetapi juga ada kemungkinan mengarah kepada tingkah laku lebih buruk. Hamalik (2008: 36) mengatakan bahwa belajar adalah modifikasi atau memperteguh kelakuan melalui pengalaman. 
Sedangkan definisi belajar menurut Gagne (1977) merupakan sejenis perubahan yang diperlihatkan dalam perubahan tingkah laku, yang keadaannya berbeda dari sebelum individu berada dalam situasi belajar dan sesudah melakukan tindakan yang serupa itu.

Menurut Mustaqim (2004:34) bahwa belajar adalah perubahan tingkah laku yang relatif tetap yang terjadi karena latihan dan pengalaman dengan kata lain yaitu suatu aktifitas atau usaha yang disengaja aktifitas tersebut menghasilkan perubahan, berupa sesuatu yang baru baik yang segera nampak atau tersembunyi tetapi juga hanya berupa penyempurnaan terhadap sesuatu yang pernah dipelajari. Perubahan - perubahan itu meliputi perubahan ketrampilan jasmani, kecepatan perseptual, isi ingatan, abilitas berfikir, sikap terhadap nilai - nilai dan inhibisi serta lain - lain fungsi jiwa (perubahan yang berkenaan dengan aspek psikis dan fisik) perubahan tersebut relatif konstan.

Menurut berbagai pengertian belajar di atas, maka pengertian belajar adalah tindakan suatu proses perubahan fisik, mental serta ilmu yang kian menambah karena adanya pengalaman. Semakin banyak belajar maka semakin banyak pula ilmu serta pengalaman yang didapat

Keberhasilan belajar ditentukan oleh beberapa faktor yang salah satunya adalah minat belajar. Purwanto (2010: 66) mengatakan bahwa minat merupakan landasan penting bagi seseorang untuk melakukan kegiatan dengan baik yaitu dorongan seseorang untuk berbuat. Djamarah (2008: 191) mengatakan minat adalah suatu rasa lebih suka dan rasa ketrikatan pada suatu hal atau aktivitas tanpa ada yang menyuruh. Sedangkan Slameto (2010: 182) mengatakan minat adalah penerimaan akan sesuatu hubungan antara diri sendiri dengan sesuatu di luar diri. Wardiana (2005: 172) mengatakan minat adalah dorongan seseorang untuk melakukan suatu pekerjaan atau kegiatan. Sedangkan Sukmadinata (2005: 81) mengatakan bahwa minat adalah perasaan yang mendorong seseorang untuk melakukan suatu kegiatan.

Minat belajar siswa dalam mengikuti pembelajaran merupakan sesuatu yang penting dalam kelancaran proses belajar mengajar. Siswa yang mempunyai minat belajar tinggi dalam proses pembelajaran dapat menunjang proses belajar mengajar untuk semakin baik, begitupun sebaliknya minat belajar siswa yang rendah maka kualitas pembelajaran akan menurun dan akan berpengaruh pada hasil belajar. Slameto (2010: 180) mengatakan bahwa mengembangkan minat terhadap sesuatu pada dasarnya adalah membantu siswa melihat bagaimana hubungan antara materi yang diharapkan untuk dipelajarinya dengan dirinya sendiri sebagai individu. Proses ini berarti menunjukkan pada siswa bagaimana pengetahuan atau kecakapan tertentu mempengaruhi dirinya, melayani tujuantujuannya, memuaskan kebutuhan-kebutuhannya. Bila siswa menyadari bahwa belajar merupakan suatu alat untuk mencapai beberapa tujuan yang dianggapnya penting, dan bila siswa melihat bahwa hasil dari pengalaman belajarnya akan membawa kemajuan pada dirinya kemungkinan besar ia akan berminat dan termotivasi untuk mempelajarinya.

Berdasarkan pengertian di atas maka minat adalah salah satu peran penting dalam dunia pendidikan terutama dalam kegiatan proses belajar mengajar. Karena minat sendiri adalah ketertarikan terhadap sesuatu, maka jika siswa tidak tertarik terhadap pembelajaran Daring maka minat belajar 
siswa akan menurun, sehingga akan memperlambat proses daya tangkap siswa terhadap materi yang disajikan dalam pembelajaran Daring.

William James, sebagaimana yang dikutip oleh Moh. Uzer Usman (2001:95) melihat bahwa minat siswa merupakan faktor utama yang menentukan derajat keaktifan belajar siswa. Jadi, minat merupakan faktor yang menentukan keterlibatan siswa secara aktif dalam belajar. Selanjutnya Kurt Singer (1987:95) mengemukakan beberapa faktor yang dapat menimbulkan minat terhadap pelajaran, sebagai berikut:

a. Pelajaran akan menarik murid jika terlihat adanya hubungan antara pelajaran dan kehidupan nyata.

b. Bantuan yang diberikan guru terhadap anak didiknya dalam mencapai tujuan tertentu.

c. Adanya kesempatan yang diberikan guru terhadap siswa untuk berperan aktif dalam proses belajar mengajar.

d. Sikap yang diperlihatkan guru dalam usaha meningkatkan minat siswa, sikap seorang guru yang tidak disukai oleh anak didik tentu akan mengurangi minat dan perhatian siswa terhadap mata pelajaran yang diajarkan oleh guru yang bersangkutan.

Menurut Djamarah (2002: 132) indikator minat belajar yaitu rasa suka/senang, pernyataan lebih menyukai, adanya rasa ketertarikan adanya kesadaran untuk belajar tanpa di suruh, berpartisipasi dalam aktivitas belajar, memberikan perhatian.

E-learning merupakan salah satu bentuk model pembelajaran yang difasilitasi dan didukung pemanfaatan teknologi infor-masi dan komunikasi. E-learning mempunyai ciri-ciri, antara lain (Clark \& Mayer 2008: 10): 1) memiliki konten yang relevan dengan tujuan pembelajaran; 2) menggunakan metode instruksional, misalnya penyajian contoh dan latihan untuk meningkatkan pembelajaran; 3) menggunakan elemen-elemen media seperti kata-kata dan gambar-gambar untuk me-nyampaikan materi pembelajaran; 4) memungkinkan pembelajaran langsung berpusat pada pengajar (synchronous e-learning) atau di desain untuk pembelajaran mandiri (asynchronous e-learning); 5) membangun pemahaman dan keterampilan yang terkait dengan tujuan pembelajaran baik secara perseorangan atau meningkatkan kinerja pembelajaran kelompok. Sedangkan menurut Darin E. Hartley (Hartley, 2001): E-Learning atau online learning adalah suatu jenis belajar mengajar yang memungkinkan tersampaikannya bahan ajar ke siswa dengan menggunakan media Internet, Intranet atau media jaringan komputer lain.

Sedangkan menurut Rusman dkk (2011: 264) e-learning memiliki karakteristik, antara lain (a) interactivity (interaktivitas); (b) independency (kemandirian); (c) accessibility (aksesibilitas); (d) enrichment (pengayaan).

E-learning dapat didefinisikan sebagai sebuah bentuk teknologi informasi yang diterapkan di bidang pendidikan dalam bentuk dunia maya. Istilah e-learning lebih tepat ditujukan sebagai usaha untuk membuat sebuah transformasi proses pembelajaran yang ada di sekolah atau perguruan tinggi ke dalam bentuk digital yang dijembatani teknologi internet (Munir, 2009: 169). 
Pembelajaran daring mempuyai banyak manfaat, yang pertama dapat membangun komunikasi dan diskusi yang sangat efisien antara guru dengan murid, kedua siswa saling berinteraksi dan berdiskusi antara siswa yang satu dengan yang lainnya tanpa melalui guru, ketiga dapat memudahkan interaksi antara siswa guru, dengan orang tua, keempat sarana yang tepat untuk ujian maupun kuis, kelima guru dapat dengan mudah memberikan materi kepada siswa berupa gambar dan vidio selain itu murid juga dapat mengunduh bahan ajar tersebut, keenam dapat memudahkan guru membuat soal dimana saja dan kapan saja (Meidawati \& Veteran Bangun Nusantara Sukoharjo, 2019).

Ada banyak media yang digunakan untuk belajar daring. Berbagai platform sudah lama menyediakan jasa ini. Sebut saja misalnya Google Clasroom, Rumah Belajar, Edmodo, Ruang Guru, Zenius, Google Suite for Education, Microsoft Office 365 for Education, Sekolahmu, Kelas Pintar. Inilah yang disebut sebagai platform microbloging (Basori, 2013). Namun perlu waktu untuk mempelajari sistem belajar melalui platform belajar daring tersebut. Jika dipahami, ada kemungkinan memberikan dampak positif pada proses pembelajaran (Wisudawati et al., 2020). Namun, guru atau dosen sekalipun belum tentu paham penggunaan media-media ini. Apalagi orang tua dengan berbagai latar belakangnya.

Penggunaan WhatsApp Grup sebagai media belajar banyak terjadi di tingkat sekolah dasar. Tentu karena berbabagai pertimbangan. Pada level pendidikan tinggi WhatsApp hanya salah satu media. Berbeda dengan sekolah dasar, dari survei yang dilakukan peneliti $100 \%$ belajar daring hanya menggunakan media WhatsApp grup (Rosarians et al., 2020) (Harususilo, 2020). Tetapi pada kenyataan sekarang media WhatsApp lah yang paling banyak diminati oleh kebanaykan jenjang sekolah dari tingkat sekolah dasar hingga perguruan tinggi. Aplikasi yang banyak digandrungi menggunakan aplikasi WhatsApp Messenger yaitu pembicaraan/diskusi secara berkelompok (Jumiatmoko, 2016). Jika ditelisik kembali, pembelajaran daring menggunakan aplikasi WhatsApp juga sudah digunakan dengan pendekatan model pembelajaran kolaborative namun masih dikombinasi dengan pembelajaran tatap muka (Prajana, 2017). Suryadi (2018) menambahkan jika dilihat dari fungsinya WhatsApp hampir sama dengan aplikasi SMS yang biasa dipergunakan di ponsel lama. Namun, pada WhatsApp ini tidak digunakan pulsa seperti biaya sms pada umumnya, tetapi menggunakan jaringan internet sesuai dengan perkembangan teknologi yang saat ini terhubung dengan jaringan dan teridentifikasi dengan nomor HandPhone (HP).

WhatsApp adalah aplikasi berbasis internet yang merupakan salah satu dampak perkembangan teknologi informasi yang paling popular. Aplikasi berbasis internet ini sangat potensial untuk dimanfaatkan sebagai media komunikasi, karena memudahkan penggunanya untuk saling berkomunikasi dan berinteraksi tanpa menghabiskan biaya banyak dalam pemakaiannya, karena whatsapp tidak menggunakan pulsa, melainkan menggunakan data internet(Pranajaya \& Hendra Wicaksono, 2017). Sedangkan Menurut Larasati, dkk (2013), WhatsApp merupakan aplikasi untuk saling berkirim pesan secara instan, dan memungkinkan kita untuk saling bertukar gambar, video, foto, pesan suara, dan dapat digunakan untuk berbagi informasi dan diskusi. Larasati menyimpulkan 
bahwa pemanfaatan aplikasi WhatsApp sebagai sarana diskusi pembelajaran ini termasuk dalam kategori efektif.

Dikutip dari wikipedia, Whatsapp adalah aplikasi pesan untuk smartphone dengan basic mirip BlackBerry Messenger. WhatsApp Messenger merupakan aplikasi pesan lintas platform yang memungkinkan kita bertukar pesan tanpa biaya SMS, karena WhatsApp Messenger menggunakan paket data internet yang sama untuk email, browsing web, dan lain-lain. Aplikasi WhatsApp Messenger menggunakan koneksi 3G atau WiFi untuk komunikasi data. Dengan menggunakan WhatsApp, kita dapat melakukan obrolan online, berbagi file, bertukar foto dan lain-lain.

Pemanfaatan program WhatsApp sangat efektif dengan dukungan fitur-fiturnya dibanding dengan aplikasi pesan instan lainnya. Kecepatan pesan tanpa waktu lama hingga tertunda, mampu beroperasi dalam kondisi sinyal lemah, kapasitas pengiriman data teks, suara, foto dan video yang besar, tanpa gangguan iklan berikut sifat penyebarannya membuat WhatsApp sebagai salah satu media alternatif dalam memberikan informasi dan meningkatkan kinerja (Andi Miladiyah, 2017).

1. Fitur - Fitur WhatsApp

a. Tanda pesan sukses terkirim, sudah diterima, dan sudah dibaca

b. Fitur ini mirip sekali dengan BlackBerry Messenger. Kalau di BlackBerry Messenger menggunakan tanda $\mathrm{D}$ dan $\mathrm{R}$, di WhatsApp menggunakan tanda centang. Satu tanda centang (berwarna abu-abu) berarti pesan berhasil dikirim, dua tanda centang (berwarna abu-abu) berarti pesan telah diterima tapi belum dibaca, dan dua tanda centang berwarna biru berarti pesan telah di baca. Apabila tidak koneksi internet, akan muncul tanda jam yang mengartikan pengiriman pesan tertunda. WhatsApp dapat mengirim file-file seperti :

1) Foto (langsung dari kamera, file manager dan media galery)

2) Video (langsung dari video kamera, file manager dan media galery)

3) Audio (langsung merekam suara, dari file manager, dari music galery)

4) Location (Anda dapat mengirim lokasi Anda dengan mengambil posisi Anda dari Google Maps)

5) Contact (mengirim detail kontak dari phonebook)

2. Fitur lain yang terdapat di WhatsApp adalah:

a. View Contact: Anda dapat melihat contact di phonebook, WhatsApp juga muncul sebagai daftar contact di phonebook

b. Avatar: Anda tidak dapat mengganti Avatar secara manual, WhatsApp akan mengambil data avatar dari Profile phonebook. Apabila menggunakan sinkronisasiFacebook dengan Phonebook, maka avatar yang muncul adalah avatar Facebook.

c. Add conversation shortcut : dapat juga menambahkan shortcut conversation ke homescreen.

d. Email Conversation : Anda pun dapat mengirim semua perbincangan melalui email. 
e. Copy/Paste : Setiap kalimat perbincangan juga dapat di copy,forward dan delete dengan menekan dan menahan kalimat tersebut dilayar.

f. Smile icon: Untuk menambahkan serunya perbincangan, Anda pun dapat menambahkan emotions dengan banyak pilihan, seperti : smile emotions, icon-icon seperti cuaca, binatang, tanaman, alat-alat musik, buku, kartu, mobil, bangunan, pesawat dan lain-lain.

g. Search : fitur dasar setiap IM, Anda dapat mencari daftar contact melalui fitur ini.

h. Call : karena pin WhatsApp ini sama dengan no telp/hp teman, Anda pun dapat melakukan panggilan langsung dari aplikasi WhatsApp ini.

i. WhatsApp Call : Pengguna bisa melakukan panggilan melalui WhatsApp dengan koneksi internet.

j. Block: digunakan untuk memblok kontak tertentu.

k. Status : seperti kebanyakan fitur IM, Status juga hadir di WhatsApp. Namun tidak seperti BBM yang menampilkan update terbaru setiap ada perubahan status dari teman, WhatsApp hanya menampilkan status dibawah nama teman, mirip dengan di Yahoo Messenger. Anda pun dapat mengganti status yang sudah tersedia di WhatsApp seperti available, busy, at school dll.

Menurut pengertian WhatsApp di atas, maka dapat disimpulkan bahwa WhatsApp adalah sebuah aplikasi untuk mengirim pesan dengan menggunakan roaming data internet untuk mengirimnya. Di dalam WhatsApp memiliki berbagai fitur diantaranya mengirim teks, gambar, video, menelpon serta video call yang terbatas jumlahnya. Maka peneliti disini menggunakan WhatsApp untuk mengirim video guru yang sedang mengajar materi yang akan disampaikan. Berdasarkan analisis peneliti dalam penelitian ini, siswa cenderung lebih menyukai pembelajarn Daring yang bersifat lebih santai tetapi mudah di pahami, yaitu pembelajaran Daring via WhatsApp dengan mengirimkan video guru yang sedang mengajar di kelas. Di sini Siswa akan dapat mengulangngulang materi pembelajaran yang disampaikan guru lewat video yang dikirim di grup WhatsApp sehingga mudah dipahami oleh siswa yang sebelumnya harus di unduh terlebih dahulu.

Maka pada penjelasan tersebut, peneliti mengambil judul penelitian yaitu Peningkatan Minat Belajar Siswa Pada Pembelajaran E-learning Via WhatsApp di Kelas X MIPA Madrasah Aliyah.

\section{METODE}

Penelitian ini dilakukan di MA Hasannah Pekanbaru. Subjek penelitian adalah seluruh siswa di kelas X MIPA MA Hasannah Pekanbaru. Penelitian ini termasuk ke dalam Penelitian Tindakan Kelas yang bertujuan untuk melihat serta menggambarkan seberapa besar peningkatan siswa dalam minat belajar melalui pembelajaran daring via WhatsApp. Dalam penelitian ini digunakan google form untuk memperoleh data-data yang dibutuhkan oleh peneliti. Insrumen penelitian tersebut berupa pertanyaan-pertanyaan yang diperuntukan siswa untuk mencari data seberapa besar minat belajar 
siswa terhadap pembelajaran Daring ini. Data yang diisi oleh siswa selanjutnya menjadikan bahan untuk memperoleh hasil dan pembahasan.

Prosedur Kerja dalam Penelitian: Penelitian dilaksanakan dalam 1 siklus Pemberian tindakan pada siklus pertama berdasarkan pada hasil refleksi awal (prasiklus). Berdasarkan refleksi awal dilakukan penelitian tindakan kelas Online (PTK-O) melalui tahapan atau prosedur perencanaan, implementasi tindakan, pengamatan dan evaluasi, dan refleksi.

Siklus 1: Siklus 1 terdiri dari : a. Perencanaan; 1). Dokumentasi kondisional meliputi daftar nilai dan lembar pertanyaan pada google form.2). Identifikasi masalah, masalah yang dihadapi dalam penelitian ini adalah kurangnya minat belajar siswa terhadap pembelajaran Daring.3). Membuat lembar observasi untuk melihat proses pembelajaran di kelas Online.4). b. Implementasi Tindakan; Pertama diberikan materi spldv, pada saat peneliti berikan soal spldv pada google form, tidak ada respon siswa untuk menjawab soal yang diberikan peneliti pada bagian tindakan ini. c. Pengamatan: tidak adanya data, baik data pra siklus, latihan maupun hasil tes siklus 1. d. Refleksi: Tidak dapat dilakukan pengukuran apakah terdapat peningkatan minat belajar siswa.

\section{HASIL DAN DISKUSI}

Penelitian ini dilaksanakan di MA Hasannah Pekanbaru dengan subjek penelitian siswa kelas X MIPA yang berjumlah 13 orang. Berikut adalah respon siswa yang disajikan oleh peneliti untuk melihat hasil peningkatan siswa walaupun tidak adanya siklus yang dapat menjadikan data dalam penelitian ini.

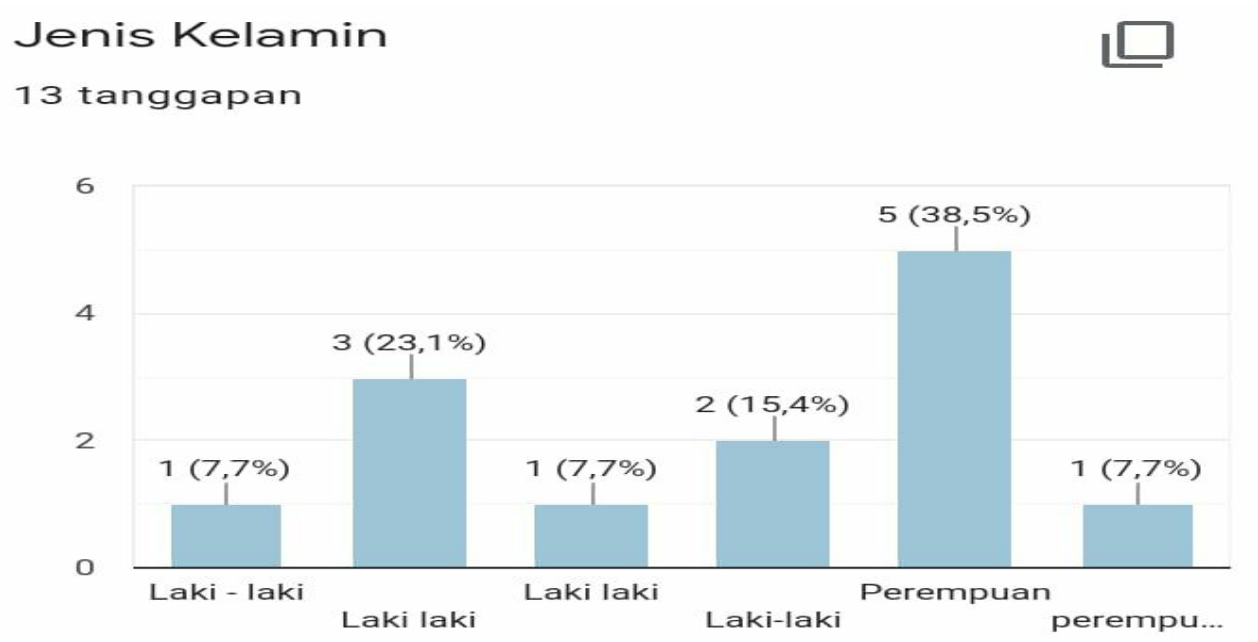

Gambar 1. Hasil Peningkatan Siswa

Gambar 1. Banyak Siswa Responden Dari gambar di atas dapat dilihat bahwasannya dalam penelitian ini subjek laki-laki di kelas X MIPA berjumlah 7 siswa, sedangkan jumlah subjek perempuan di kelas X MIPA sebanyak 6 siswi. 


\section{Apakah metode pembelajaran yang digunakan}

13 tanggapan
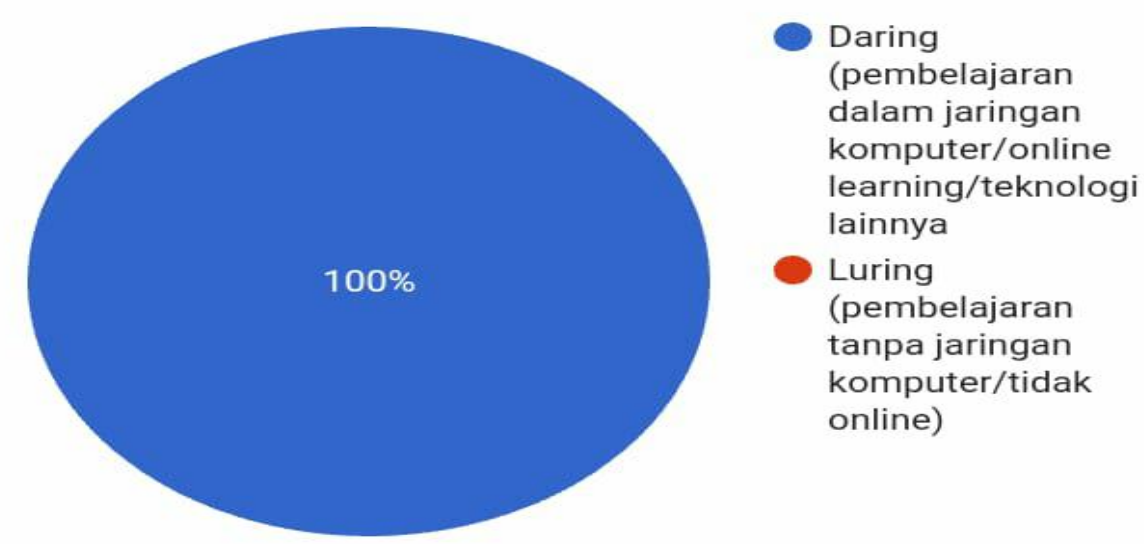

Gambar 2. Metode Pembelajaran yang Digunakan

Gambar 2. Metode Pembelajaran Yang Digunakan Dari gambar di atas dapat dilihat bahwasannya siswa-siswi kelas X MIPA memberikan tanggapan bahwasannya mereka belajar melalui Dalam Jaringan (daring) yaitu menngunakan teknologi berupa handphone, PC dan sejenisnya.

\section{Menurut saudara mengenai Sekolah menggunakan metode pembelajaran Daring}

13 tanggapan

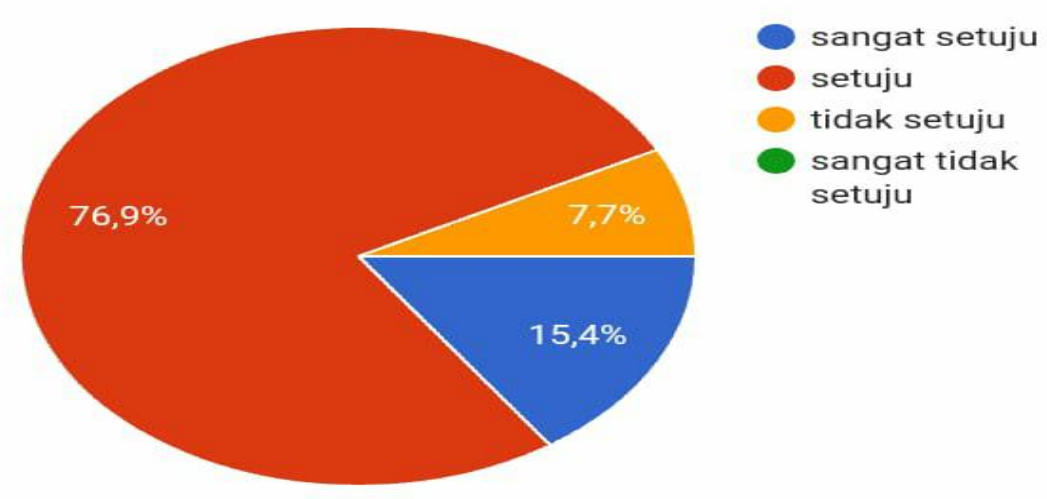

Gambar 3. Pendapat Peserta Didik Mengenai Pembelajaran Daring

Gambar 3. Dari gambar di atas dapat dilihat bahwasannya siswa-siswi kelas X MIPA 76,9\% cukup setuju dengan pembelajaran Daring, 7,7\% siswa lainnya tidak setuju dengan pembelajaran Daring dan 15,4\% siswa kelas X MIPA sangat setuju menggunakan penelajaran Daring. 

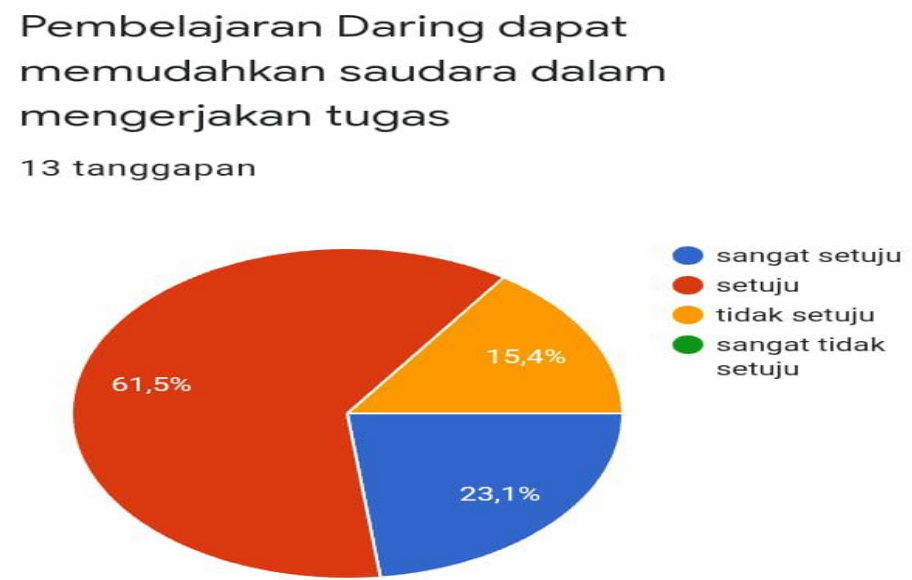

Gambar 4. Hasil Respon Peserta Didik

Gambar 4. Pada gambar di atas dapat dilihat bahwasannya siswa setuju dan sangat setuju bahwa pembelajaran daring memudahkan dalam mengerjakan tugas, tetapi $15,4 \%$ siswa dari jumlah keseluruhan tidak setuju kalau pembelajaran daring ini memudahkan dalam pengerjaan tugas.

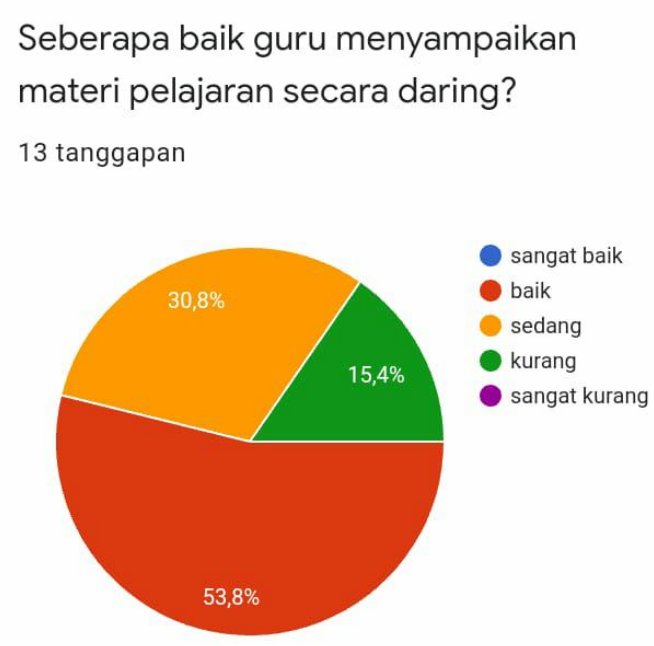

Gambar 5. Hasil Respon Peserta Didik

Gambar 5. Pada gambar di atas dapat dilihat bahwasannya guru dalam mengajar menggunakan pembelajaran Daring kurang baik, hal ini disampaikan oleh siswa yang menilai guru masih kurang baik dalam menyampaikan pembelajaran Daring dengan persentasi penilaian siswa mencapai $15,4 \%$, sedangkan siswa lainnya menilai guru sudah cukup baik dan baik dengan persentasi sedang yaitu $30,8 \%$ dan baik mencapai $53,8 \%$. 


\section{Seberapa baik Saudara memahami materi pembelajaran daring?}

13 tanggapan

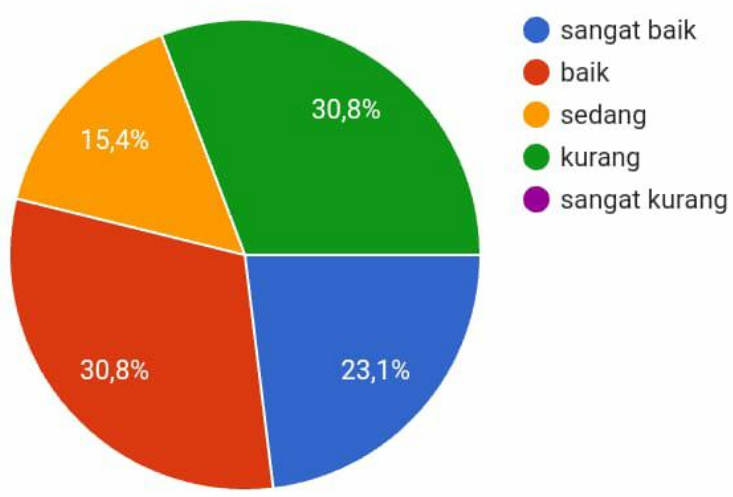

Gambar 6. Hasil Respon Peserta Didik

Gambar 6. Pada gambar di atas dapat di lihat bahwasannya dalam pembelajaran Daring siswa yang mampu menyerap dan mehamai pembelajaran Daring secara sangat baik sebanyak $23,1 \%$, baik sebanyak $30,8 \%$, sedang sebanyak $15,4 \%$ dan kurang baik sebanyak $30,8 \%$.

\section{KESIMPULAN}

Pada Hasil dan Pembahasan maka dapat disimpulkan bahwasannya ada beberapa siswa yang kurang minat dalam pembelajaran daring ini, beberapa faktor yang mempengaruhinya salah satunya adalah kurangnya rasa senang yang didapat saat melakukan pembelajaran Daring ini. salah satu indikator minat belajar seperti yang disampaikan oleh Djamarah (2002:132) salah satunya adalah rasa senang dan ketertarikan terhadap suatu objek. Maka, jika dalam pembelajaran tidak ada memiliki rasa senang dalam diri siswa maka siswa tidak akan mengikuti pembelajaran Daring secara efektif dan baik. Perlu upaya yang serius dari seluruh pihak agar membangun sisitem pembelajaran daring yang efektif menjadikan daya tarik belajar untuk siswa, sehingga muncul lah minat belajar pada diri siswa. Kuat dugaan pandemi Covid-19 tidak akan berakhir dalam waktu dekat sehingga perlu evaluasi media pembelajaran daring yang sesuai dengan kebutuhan guru dan siswa.

\section{UCAPAN TERIMA KASIH}

Terimakasih diucapkan kepada Kepala MA Hasanah Kota Pekanbaru yang sudah memberikan izin dalam melaksanakan penelitian ini. Kepada Guru Wali Kelas X MA Hasanah Kota Pekanbaru yang sudah berpartisipasi dalam melaksanakan penelitian ini serta peserta didik Kelas X MIPA. Kepada Ibu Zulfah, M.Pd yang sudah memberikan izin dalam dan mendukung melaksanakan 
penelitian ini serta membimbing penulis. Serta Orang Tua yang telah mendukung dan memotivasi penulis.

\section{REFERENSI}

Budi Santoso, H., \& Subagyo. (2017). PENINGKATAN AKTIFITAS DAN HASIL BELAJAR DENGAN METODE PROBLEM BASIC LEARNING (PBL) PADA MATA PELAJARAN TUNE UP MOTOR BENSIN SISWA KELAS XI DI SMK INSAN CENDEKIA TURI SLEMAN TAHUN AJARAN 2015/2016. Jurnal Taman Vokasi, 5 nomor 1, 40-45.

Daheri, M., Juliana, Deriwanto, \& Dibul, A. A. (2020). Efektifitas WhatsApp sebagai Media Belajar Daring. Jurnal Basicedu, 4 nomor 4, 775-783.

N.A, Y. (2020). Efektifitas Pembelajaran Statistika Matematika melalui Media WhatsApp Gruop Ditinjau dari Hasil Belajar Mahasiswa (Masa Pandemik Covid 19). Jurnal Pendidikan Matematika Reflesia, 2 nomor 3, 232.243.

P. Buloto, Y. (2018). Implementasi Pendekatan Pembelajaran 5 M Dalam Meningkatkan Minat Belajar Siswa Pada Mata Pelajaran IPA di SMP Negeri 4 Gorontalo. JPs: Jurnal Riset dan Pengembangan Ilmu Pengetahuan, 03 nomor 1, 126-137.

Rahartri. (2019). “WHATSAPP” MEDIA KOMUNIKASI EFEKTIF MASA KINI (STUDI KASUS PADA LAYANAN JASA INFORMASI ILMIAH DI KAWASAN PUSPIPTEK). VISI PUSTAKA, 21 nomor 2, 147-155.

Rusmiati. (2017). PENGARUH MINAT BELAJAR TERHADAP PRESTASI BELAJAR BIDANG STUDI EKONOMI SISWA MA AL FATTAH SUMBERMULYO. UTILITY: Jurnal Ilmiah Pendidikan dan Ekonomi, 1 nomor 1, 21-36.

Sulistyo Hanum, N. (2013). KEEFEKTIFAN E-LEARNING SEBAGAI MEDIA PEMBELAJARAN (STUDI EVALUASI MODEL PEMBELAJARAN E-LEARNING SMK TELKOM SANDHY PUTRA PURWOKERTO). Jurnal Pendidikan Vokasi, 3 nomor 1, 90-102.

Susilowati, E. (2020). Bagaimana Pembelajaran Daring di Tengah Wabah Covid 19 melalui Grup WhatsApp? Jurnal Pendidikan Matematika Raflesia, 05 nomor 03, 1-25.

Syardiansah. (2016). Hubungan Motivasi Belajar dan Minat Belajar terhadap Prestasi Belajar Mahasiswa Mata Kuliah Pengantar Manajemen (Studi kasus Mahasiswa Tingkat I EKM A Semester II. JURNAL MANAJEMEN DAN KEUANGAN, 5 nomor 1, 440-448.

Yunitasari, R., \& Hanifah, U. (2020). Pengaruh Pembelajaran Daring terhadap Minat Belajar Siswa Pada Masa COVID-19. Edukatif : Jurnal Ilmu Pendidikan, 2 nomor 3, 232-243. 